\title{
Osteogenic Enhancement of Zirconia-Toughened Alumina with Silicon Nitride and Bioglass ${ }^{\circledR}$
}

\author{
Giuseppe Pezzotti ${ }^{1,2,3,4, *}$, Elia Marin ${ }^{1,5}$ (D), Matteo Zanocco ${ }^{1,2}$, Francesco Boschetto ${ }^{1,2}$, \\ Wenliang Zhu ${ }^{1}$, Bryan J. McEntire ${ }^{6}$, B. Sonny Bal ${ }^{6}$, Tetsuya Adachi ${ }^{5}{ }^{\circledR}$, Toshiro Yamamoto ${ }^{5}$, \\ Narisato Kanamura ${ }^{5}$ and Osam Mazda ${ }^{2}$ \\ 1 Ceramic Physics Laboratory, Kyoto Institute of Technology, Sakyo-ku, Matsugasaki, Kyoto 606-8585, Japan; \\ elia-marin@kit.ac.jp (E.M.); matteo.zanocco@gmail.com (M.Z.); boschetto.cesc@gmail.com (F.B.); \\ wlzhu@kit.ac.jp (W.Z.) \\ 2 Department of Immunology, Graduate School of Medical Science, Kyoto Prefectural University of Medicine, \\ Kamigyo-ku, 465 Kajii-cho, Kyoto 602-8566, Japan; omazda@gmail.com \\ 3 Department of Orthopedic Surgery, Tokyo Medical University, 6-7-1 Nishi-Shinjuku, Shinjuku-ku, \\ Tokyo 160-0023, Japan \\ 4 The Center for Advanced Medical Engineering and Informatics, Osaka University, 2-2 Yamadaoka, Suita, \\ Osaka 565-0854, Japan \\ 5 Department of Dental Medicine, Graduate School of Medical Science, Kyoto Prefectural University of \\ Medicine, Kamigyo-ku, Kyoto 602-8566, Japan; t-adachi@koto.kpu-m.ac.jp (T.A.); \\ yamamoto@koto.kpu-m.ac.jp (T.Y.); n-kanamura@koto.kpu-m.ac.jp (N.K.) \\ 6 SINTX Technologies Corporation, 1885 West 2100 South, Salt Lake City, UT 84119, USA; \\ BMcEntire@sintx.com (B.J.M.); SBal@sintx.com (B.S.B.) \\ * Correspondence: pezzotti@kit.ac.jp
}

Received: 28 August 2019; Accepted: 30 September 2019; Published: 4 October 2019

\begin{abstract}
Alumina $\left(\mathrm{Al}_{2} \mathrm{O}_{3}\right)$ ceramic implants do not stimulate osteoblasts in vivo. Surface alterations targeted at changing the chemistry or topography have been proposed to enhance the bioactivity of alumina. This surface modification is intended to improve oxide bioceramic's ability to integrate with the biological environment and, in particular, to rapidly osteointegrate. In this study, the surface of zirconia-toughened alumina (ZTA) was functionalized using two methods: (i) Surface laser-patterning and successive filling of patterned wells with powder mixtures of bioglass and $\mathrm{Si}_{3} \mathrm{~N}_{4}$; and, (ii) $\mathrm{Si}_{3} \mathrm{~N}_{4}$ coating by pulse-laser sintering. Functionalized ZTA surfaces were characterized with vibrational spectroscopy, biological testing, and laser microscopy. Both enhancements resulted in osteoblast activation, a property that is relevant to osteosynthesis.
\end{abstract}

Keywords: zirconia-toughened alumina; silicon nitride; surface functionalization; pulsed laser technology; osteogenesis

\section{Introduction}

During bone formation, organic matrix (i.e., predominantly collagen type I) is synthesized by cells secreting a variety of glycoproteins, genetic markers, and bone sialoprotein [1]. A favorable environment for cellular apatite mineralization relies on local supersaturation of extra-cellular fluids with osteoblastic alkaline phosphatase (ALP), pyrophosphatase activity, and osteocalcin production. ALP increases phosphate concentration by cleaving phosphate groups; pyrophosphatase degrades pyrophosphate, which inhibits phosphate cleavage; and osteocalcin binds calcium [1,2]. The surface chemistry of orthopaedic implants designed to promote bone formation at tissue/implant interface should promote such chemical processes [3]. 
Although ceramic materials are considered to be bioinert [4,5], they can in fact stimulate or suppress osteoblastic activity [6,7]. For example, silicon nitride $\left(\mathrm{Si}_{3} \mathrm{~N}_{4}\right)$ ceramic implants are known to accelerate bone repair because of the surface chemistry of the material [8-11]. The release of silicic acid and reactive nitrogen species (RNS) on $\mathrm{Si}_{3} \mathrm{~N}_{4}$ surfaces enhances osteogenic activity in osteosarcoma and mesenchymal cells [8-10]. Analyses of a retrieved $\mathrm{Si}_{3} \mathrm{~N}_{4}$ human cervical fusion implant have confirmed the incorporation of silicon and nitrogen into the crystal lattice of native hydroxyapatite [11].

Data have also shown that hydrolysis at $\mathrm{Si}_{3} \mathrm{~N}_{4}$ surfaces releases $\mathrm{Si}$ and RNS ions that favor bone formation, while $\mathrm{Al}_{2} \mathrm{O}_{3}$ surfaces lead to the elution of $\mathrm{Al}^{3+}$ and reactive oxygen species (ROS) instead [12]. $\mathrm{Al}^{3+}$ ions inhibit mineralization by slowing hydroxyapatite crystal formation and altering the influx and efflux of calcium from bone cells [13]. Moreover, the formation of ROS leads to oxidative stress in cells with significant perturbation of their normal anti-oxidative system [14]. In vivo and in vitro data have shown that $\mathrm{Al}^{3+}$ and ROS-induced oxidative stress activates cell apoptotic signaling pathways [15-17]. ROS cause damage to cell proteins, lipids, and DNA; target important regulator pathways for calcium and its intracellular receptor calmodulin; and, ultimately, lead to osteoblast apoptosis [18-21]. Because of these properties, alumina orthopaedic implants are limited to low-wear applications, such as the bearings of prosthetic hip joints.

We sought to modulate the surface bioactivity of zirconia-toughened-alumina (ZTA), a material commonly used in prosthetic hip bearings using two approaches: (i) Surface laser patterning and successive filling of the patterned wells with powder mixtures of bioglass and $\mathrm{Si}_{3} \mathrm{~N}_{4}$; and, (ii) Deposition of a micrometer thick $\mathrm{Si}_{3} \mathrm{~N}_{4}$ layer using an automatic 3D-additive laser-sintering procedure. Our hypothesis was that these surface treatments would alter the $\mathrm{Al}^{3+} / \mathrm{ROS}$ surface chemistry of the oxide ZTA ceramic into the $\mathrm{Si}^{4+} / \mathrm{RNS}$ type, without affecting mechanical properties.

\section{Experimental Procedures}

\subsection{Surface Functionalization Procedures}

ZTA samples were machined from $36 \mathrm{~mm}$ diameter femoral heads (Biolox ${ }^{\circledR}$ delta, CeramTec, $\mathrm{GmbH}$, Plochingen, Germany; year of production: 2014). Squared samples $10 \mathrm{~mm} \times 10 \mathrm{~mm}$ with thickness of $3 \mathrm{~mm}$ were cut using a slow-speed diamond coated blade and polished to a roughness $0.22 \pm 0.1 \mu \mathrm{m}$ as measured by laser microscope.

\subsubsection{Laser-Patterning Procedure}

Laser-patterning of ZTA samples was done with a Vision LWI V ERGO-Workstation equipped with an Nd:YAG laser (wavelength of $1064 \mathrm{~nm}$ ). Focusing distance, nominal maximum power, and burst energy were set at $250 \mathrm{~mm}, 17 \mathrm{~kW}$, and $70 \mathrm{~J}$, respectively, while the applied potential and discharge time were regulated in the range $160 \sim 500 \mathrm{~V}$ and $1 \sim 20 \mathrm{~ms}$, respectively. The laser-patterning workstation was equipped with a gas nozzle connected to an Argon source at $1.2 \mathrm{~atm}$ to locally limit the presence of oxygen at the location of laser impingement. A motorized x-y stage with a precision of $10 \mu \mathrm{m}$ was used to align the sample with the laser source and to produce a regular grid of equidistant wells $500 \mu \mathrm{m}$ in diameter with an interspace of $1.0 \mathrm{~mm}$.

Standard 45S5 Bioglass ${ }^{\circledR}$ powder (Mo-Sci Corporation, Rolla, MO, USA) was used to fill the patterned wells. The composition in wt. $\%$ of the Bioglass ${ }^{\circledR}$ was, as follows: $45 \% \mathrm{SiO}_{2}, 24.5 \% \mathrm{CaO}$, $24.5 \% \mathrm{Na}_{2} \mathrm{O}, 6 \% \mathrm{P}_{2} \mathrm{O}_{5}$. The Bioglass ${ }^{\circledR}$ powder was mixed with 5 or $10 \mathrm{~mol} . \% \mathrm{~nm}$-sized $\alpha-\mathrm{Si}_{3} \mathrm{~N}_{4}$ powder (SN-E10, Ube Co., Ube City, Japan). Powder mixtures of Bioglass ${ }^{\circledR}$ with 5 and 10 mol.\% (corresponding to 5.51 and $10.69 \mathrm{wt} . \%) \alpha-\mathrm{Si}_{3} \mathrm{~N}_{4}$ were homogenized and melted in a platinum crucible in nitrogen gas atmosphere. After quenching, the melts were crushed into fine powder. Pure Bioglass ${ }^{\circledR}$ and Bioglass ${ }^{\circledR}$ mixtures with 5 and $10 \mathrm{wt} . \% \mathrm{Si}_{3} \mathrm{~N}_{4}$ were used to fill the wells of different ZTA samples $(n=6$ for each type of filler). A schematic draft of the patterning and powder feeding procedures is shown in Figure 1a. The sample cross-section during excavation of a cylindrical well on the ZTA surface by the pulsed laser beam is depicted in Figure 1b. 

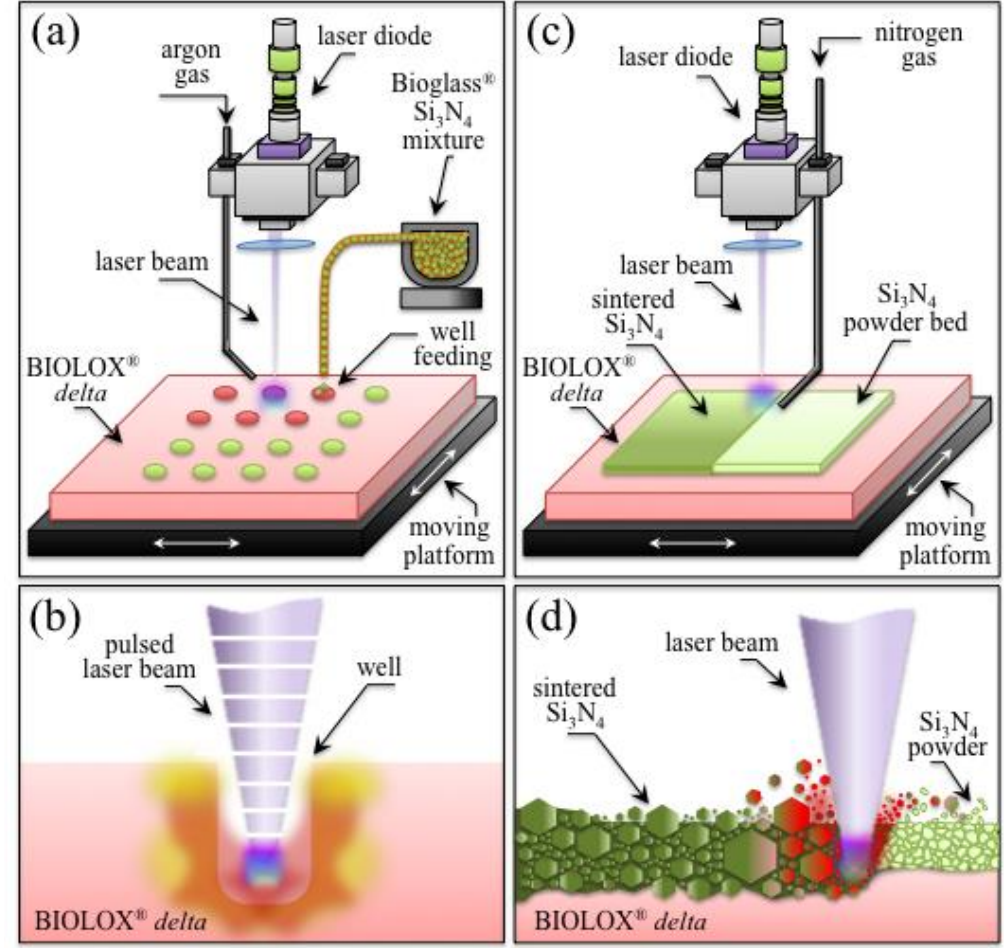

Figure 1. Schematic drafts of: (a) surface laser patterning on ZTA (zirconia toughened alumina) substrate and filling of the patterned wells with powder mixtures of Bioglass ${ }^{\circledR}$ and $\mathrm{Si}_{3} \mathrm{~N}_{4}$; (b) ZTA sample cross-section during laser excavation of a well according to the process depicted in (a); (c) deposition of a micrometer thick $\mathrm{Si}_{3} \mathrm{~N}_{4}$ layer using an automatic 3D-additive laser-sintering procedure; and, (d) cross section of the $\mathrm{Si}_{3} \mathrm{~N}_{4}$ coating/laser interaction during the process depicted in (c).

\subsubsection{Laser-Sintering Procedure}

The starting micrometric powder used for laser-sintering the $\mathrm{Si}_{3} \mathrm{~N}_{4}$ coating on the ZTA substrate consisted of $\beta-\mathrm{Si}_{3} \mathrm{~N}_{4}$ (SINTX Co., Salt Lake City, UT, USA) mixed with 6 wt. \% yttrium oxide $\left(\mathrm{Y}_{2} \mathrm{O}_{3}\right.$, Grade C, H.C. Starck, Munich, Germany) and 4 wt.\% aluminium oxide $\left(\mathrm{Al}_{2} \mathrm{O}_{3}\right.$, SA8-DBM, Baikowski/Malakoff, Charlotte, NC, USA). The workstation and the Nd:YAG laser were the same as those described above. Successive layers of $\mathrm{Si}_{3} \mathrm{~N}_{4}$ powder were placed on the water-wet surface of ZTA samples and the pulse laser repeatedly impinged to sinter/densify it.

The conditions applied to achieve $\mathrm{Si}_{3} \mathrm{~N}_{4}$-coating densification were the following: laser wavelength $1064 \mathrm{~nm}$, max pulse energy: 70 joule, peak power $17 \mathrm{~kW}$, voltage range $400 \mathrm{~V}$, pulse time $4 \mathrm{~ms}$, and spot size $2 \mu \mathrm{m}$. The apparatus operated under a constant flux of nitrogen gas flow in order to limit $\mathrm{Si}_{3} \mathrm{~N}_{4}$ decomposition and oxidation. The operation was repeated until obtaining a homogeneous $\mathrm{Si}_{3} \mathrm{~N}_{4}$ coating with thickness, $t=15 \pm 5 \mu \mathrm{m}$, over the entire surface of the ZTA substrate. A schematic draft of the overall laser-sintering procedure is schematically depicted in Figure 1c. The sample/laser interaction during sintering/densification of the $\mathrm{Si}_{3} \mathrm{~N}_{4}$ coating from the powder bed is shown in cross section in Figure 1d.

\subsection{Surface Characterization}

The surface morphology of the textured ZTA surface before and after filling with Bioglass ${ }^{\circledR} / \mathrm{Si}_{3} \mathrm{~N}_{4}$ powder mixtures was characterized with a confocal scanning laser microscope (Laser Microscope 3D and Profile measurements, Keyence, VKx200 Series, Osaka, Japan) capable of high-resolution optical images with depth selectivity. All images were collected using 20× magnification. Scanning Electron Microscopy (SEM) and Energy Dispersive X-ray Spectroscopy (EDS) (JSM-700 1F, JEOL, Tokyo, Japan) were used to acquire high-resolution images and chemical composition maps of $\mathrm{Si}_{3} \mathrm{~N}_{4}$-coated substrates. 
FTIR spectra were obtained using a high sensitivity spectroscope (Spectrum 100FT-IR Spotlight400; Perkin-Elmer Inc., Waltham, MA, USA). The spectral resolution of this equipment was $0.4 \mathrm{~cm}^{-1}$. Average FTIR spectra were computed for each substrate from eight independent measurements. Pre-processing of raw data, which included baseline subtraction, smoothing, normalization, and fitting of the raw spectra, were performed using " $R$ " [22].

\subsection{Cell Culture and Biological Tests}

SaOS-2 human osteosarcoma cells were cultured and incubated in $4.5 \mathrm{~g} / \mathrm{L}$ glucose DMEM (D-glucose, L-Glutamine, Phenol Red, and Sodium Pyruvate; Nacalai Tesque, Kyoto, Japan) supplemented with $10 \%$ fetal bovine serum. The cells were then kept proliferating in petri dishes for $24 \mathrm{~h}$ at $37^{\circ} \mathrm{C}$. After adjusting the final cell concentration at $5 \times 10^{5} \mathrm{cell} / \mathrm{mL}$, the cultured cells were deposited on the surface of $\mathrm{Si}_{3} \mathrm{~N}_{4}$-coated and uncoated ZTA substrates ( $n=3$ each type) previously sterilized by exposure to UV light. Osteoconductivity tests were conducted with seeding the cells in an osteogenic medium (DMEM supplemented with $50 \mu \mathrm{g} / \mathrm{mL}$ ascorbic acid, $10 \mathrm{mM} \beta$-glycerol phosphate, $100 \mathrm{mM}$ hydrocortisone, and $\sim 10 \%$ fetal bovine calf serum), and then incubating the samples for 7 days at $37^{\circ} \mathrm{C}$. The medium was changed twice during the week of incubation.

Immunocytostaining was performed with fixing the SaOS-2 cells with $4 \%$ paraformaldehyde for $15 \mathrm{~min}$ and then incubating the samples for $30 \mathrm{~min}$ at room temperature with the following primary antibodies: mouse anti-human Gla osteocalcin (TakaraBio, Kusatsu-shi, Japan) and rabbit anti-human osteopontin (dilution = 1:500) (IBL, Maebashi-Shi, Gunma, Japan). The cells were incubated with fluorescence conjugated and secondary antibodies Goat anti-Mouse Antibody FITC Conjugated (Bethyl Laboratories, Montgomery, TX, USA) and Goat anti-Rabbit Antibody PE Conjugated and (1:200) (Thermo Fisher Scientific, Waltham, MA, USA). Cell nuclei were stained with stained with Hoechst33342 (1:100) (Dojindo, Kumamoto-Shi, Japan). The stained samples were observed under a fluorescence microscope (BZX710; Keyence, Osaka, Japan). Confocal scanning laser microscopy images were obtained with a 3D laser confocal microscope (OLS4000-SAT; Olympus Co., Tokyo, Japan) in order to assess the volumetric amounts per unit area of the bone tissue produced by the SaOS-2 cells after one-week exposure to the substrates. The amounts of osteocalcin and osteopontin in the deposited bony tissue were also estimated by direct pixel counting on fluorescence micrographs using automatic software.

\subsection{Statistical Analyses}

Data relating to osteogenesis were analyzed by calculating their mean value \pm one standard deviation. The Student's $t$-test was used to detect statistically significant differences between data, $p$ values $<0.01$ being considered statistically significant and labeled with an asterisk in the figures.

\section{Experimental Results}

\subsection{Laser Patterned and Bioglass ${ }^{\circledR} / S_{3} N_{4}$-Filled ZTA Surfaces}

Figure $2 a, b$ show high-magnification images of a laser-drilled well on the ZTA surface as obtained by optical microscopy and laser topography, respectively. Similar images for the well after filling with Bioglass ${ }^{\circledR} / \mathrm{Si}_{3} \mathrm{~N}_{4}$ powder are shown in Figure $2 \mathrm{c}, \mathrm{d}$, respectively. Preliminary calibrations, which were shown in a previous paper [23], located the optimal conditions for patterning the ZTA surface.

As shown in Figure 2, pulsed-laser drilling produced wells of a regular circular shape and with relatively sharp contours. Of note, ZTA partially melted under the laser beam; the molten material was ejected from the well producing some roughening in the neighborhood of the well border. Filling of the laser-patterned wells was done by first pressing the Bioglass ${ }^{\circledR} / \mathrm{Si}_{3} \mathrm{~N}_{4}$ powder mixtures onto the ZTA surface, followed by manual removal of excess materials with a sharp blade. The powder mixtures adhered to the internal walls of the wells. In this study, we selected a diameter of $500 \mu \mathrm{m}$ for the patterned wells, consistent with pore sizes used in bone fusion implants clinically [24-27]. Figure 3a,b 
show a $4 \times 4$ grid of wells $500 \mu \mathrm{m}$ in diameter patterned on the ZTA surface as imaged by optical and laser scanning microscopies, respectively. An in-depth characterization of the morphology of the wells is shown in Figure 3c. This latter characterization revealed a regular cylindrical shape for the wells with an irregular morphology for the bottom surface at depths comparable with the well diameter. Results of optical and laser microscopy showing Bioglass ${ }^{\circledR} / \mathrm{Si}_{3} \mathrm{~N}_{4}$ powder filling of the wells are given in Figure 3d,f, respectively. These latter observations showed that the wells were completely filled with the powder mixture.
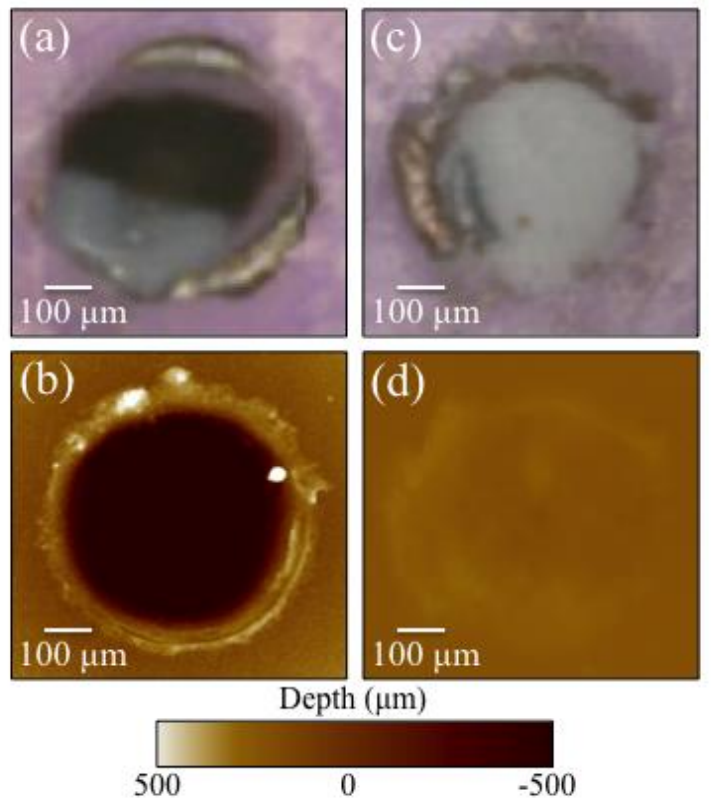

Figure 2. High-magnification images of a laser-drilled well on the ZTA surface: (a) optical microscopy and (b) laser topography; optical and laser images of the well after filling with Bioglass ${ }^{\circledR} / \mathrm{Si}_{3} \mathrm{~N}_{4}$ powder in $(\mathrm{c}, \mathrm{d})$, respectively.

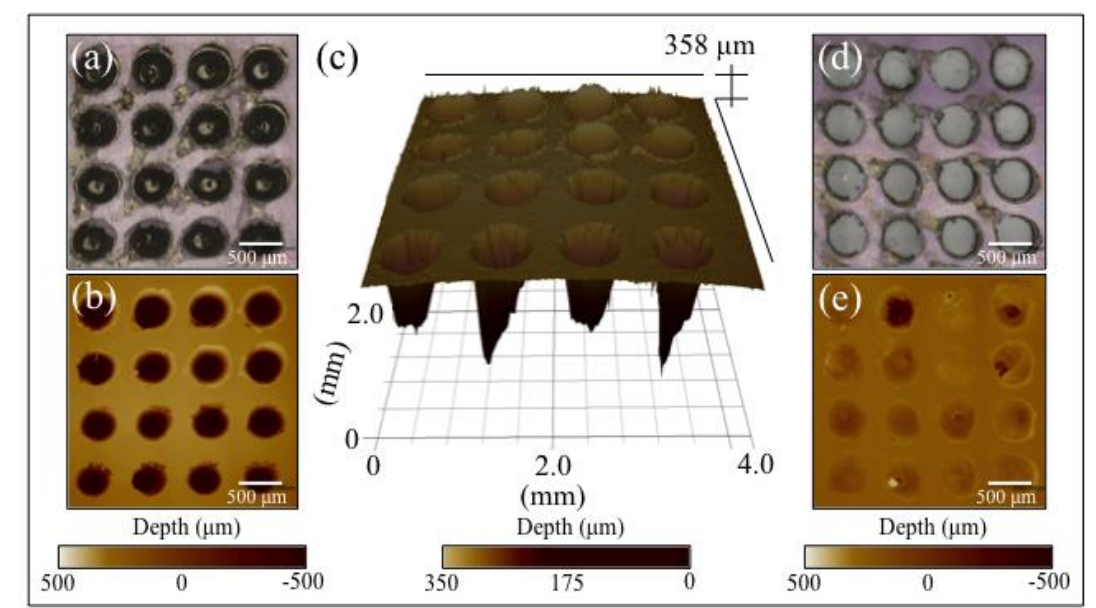

Figure 3. (a) optical and (b) laser micrographs of a $4 \times 4$ grid of wells $500 \mu \mathrm{m}$ in diameter patterned on the ZTA surface; (c) three-dimensional laser microscopy characterization of the morphology of the wells; optical and laser images of the well grid after filling with Bioglass ${ }^{\circledR} / \mathrm{Si}_{3} \mathrm{~N}_{4}$ powder in $(\mathbf{d}, \mathbf{e})$, respectively.

Figure 4 shows the results of fluorescence microscopy obtained on (a) pristine ZTA surface, (b) patterned ZTA surface, (c) patterned ZTA surface filled with Bioglass ${ }^{\circledR}$ powder only, (d) patterned ZTA surface filled with Bioglass ${ }^{\circledR} / 5 \mathrm{wt} . \% \mathrm{Si}_{3} \mathrm{~N}_{4}$ powder mixture, and (e) patterned ZTA surface filled 
with Bioglass ${ }^{\circledR} / 10$ wt.\% $\mathrm{Si}_{3} \mathrm{~N}_{4}$ powder mixture, after exposure to SaOS-2 cells for 1 week. Nuclei (blue), osteopontin (red), and osteocalcin (green) are tagged by fluorescence microscopy in the upper, middle, and bottom images of each section of Figure 4. After exposure for 1 week to SaOS-2 cells, the pristine ZTA substrate (Figure 4a) showed no cell proliferation and weak signals of osteocalcin and osteopontin, indicating a nearly absent bioactive response to osteoblasts. Similarly, the patterned and unfilled ZTA sample (Figure $4 \mathrm{~b}$ ) showed no signals and very weak osteocalcin/osteopontin signals within the wells and on flat regions, respectively.

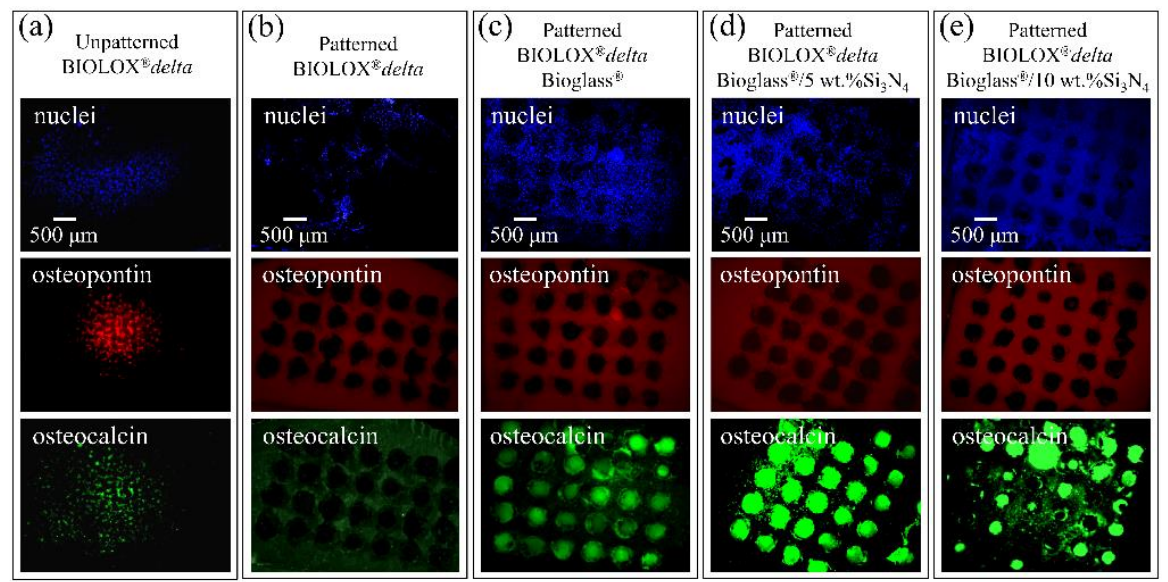

Figure 4. Fluorescence microscopy results on (a) unpatterned ZTA, (b) patterned ZTA, (c) patterned ZTA filled with Bioglass ${ }^{\circledR} / 5 \mathrm{wt}$. $\% \mathrm{Si}_{3} \mathrm{~N}_{4}$ powder mixture, and (d) patterned ZTA filled with Bioglass ${ }^{\circledR} / 10$ wt. $\% \mathrm{Si}_{3} \mathrm{~N}_{4}$ powder mixture. The samples were exposed to SaOS-2 cells for 1 week.

Cell proliferation and osteocalcin/osteopontin synthesis by osteoblasts were improved in patterned ZTA surfaces filled with Bioglass ${ }^{\circledR}$ only (Figure 4c). Cell proliferation (blue signal) and osteopontin (red signal) expression were enhanced on patterned ZTA surfaces filled with Bioglass ${ }^{\circledR} / \mathrm{Si}_{3} \mathrm{~N}_{4}$ mixtures, with higher $\mathrm{Si}_{3} \mathrm{~N}_{4}$ fractions showing stronger the blue and red fluorescence signals (cf. Figure $4 \mathrm{~d}, \mathrm{e}$ ). Green osteocalcin fluorescence, localizing mineralized tissue, was detected not only in the filled wells, but also in the un-patterned regions of the ZTA surface when the wells were filled with Bioglass ${ }^{\circledR} / \mathrm{Si}_{3} \mathrm{~N}_{4}$ mixtures.

Figure 5 summarizes quantitative laser microscopy data in terms of area coverage and specific volume of osteoblastic tissue expression on different substrates. Both data sets were computed by excluding well areas to improve accuracy in comparing different samples, because of difficulty in evaluating strongly fluorescent areas. Area coverage and specific volume of biological tissue on ZTA patterned with Bioglass ${ }^{\circledR} / \mathrm{Si}_{3} \mathrm{~N}_{4}$ mixtures were $\sim 200 \%$ and $\sim 250 \%$ higher than that of unpatterned ZTA. There was no statistically significant difference among patterned ZTA samples filled with only Bioglass ${ }^{\circledR}$ and different Bioglass ${ }^{\circledR} / \mathrm{Si}_{3} \mathrm{~N}_{4}$ mixtures outside the well areas. Figure 4 shows a strong increase in green fluorescence signals from the patterned ZTA surfaces when the powder mixture filling the wells included a fraction of $\mathrm{Si}_{3} \mathrm{~N}_{4}$ powder. While Bioglass ${ }^{\circledR}$ was stimulatory, the addition of $\mathrm{Si}_{3} \mathrm{~N}_{4}$ further enhanced osteoblast proliferation (cf. Figure $4 \mathrm{c}, \mathrm{d}$ ). Figure $6 \mathrm{a}$ shows the results of FTIR characterizations on the full set of unpatterned, patterned, and patterned/filled ZTA samples. Therefore, the addition of Bioglass ${ }^{\circledR}$ led to a significant increase in signal intensity in the spectral region at around $1000 \mathrm{~cm}^{-1}$, which represents mineral hydroxyapatite, and the further addition of $\mathrm{Si}_{3} \mathrm{~N}_{4}$ to Bioglass ${ }^{\circledR}$ led to an increase in relative intensity of signals at $\sim 1500 \mathrm{~cm}^{-1}$, which are associated with amides, and represent the biological matrix of bone tissue.

Consistent with fluorescence data in Figure 4 and their quantification in Figure 5, no mineralized tissue was detected on either pristine or patterned ZTA surfaces. Figure $6 \mathrm{~b}$ gives a plot of intensity ratios between apatite and organic matrix signals in the FTIR spectra as a function of the type of ZTA substrate. Addition of Bioglass ${ }^{\circledR}$ in the patterned wells led to an increase in the intensity of mineral 
hydroxyapatite bands. Further addition of $10 \mathrm{wt} . \%$ fraction of $\mathrm{Si}_{3} \mathrm{~N}_{4}$ in the filler mixture brought the FTIR inorganic/organic band ratio of ZTA in the range recorded for healthy bone tissue [28].

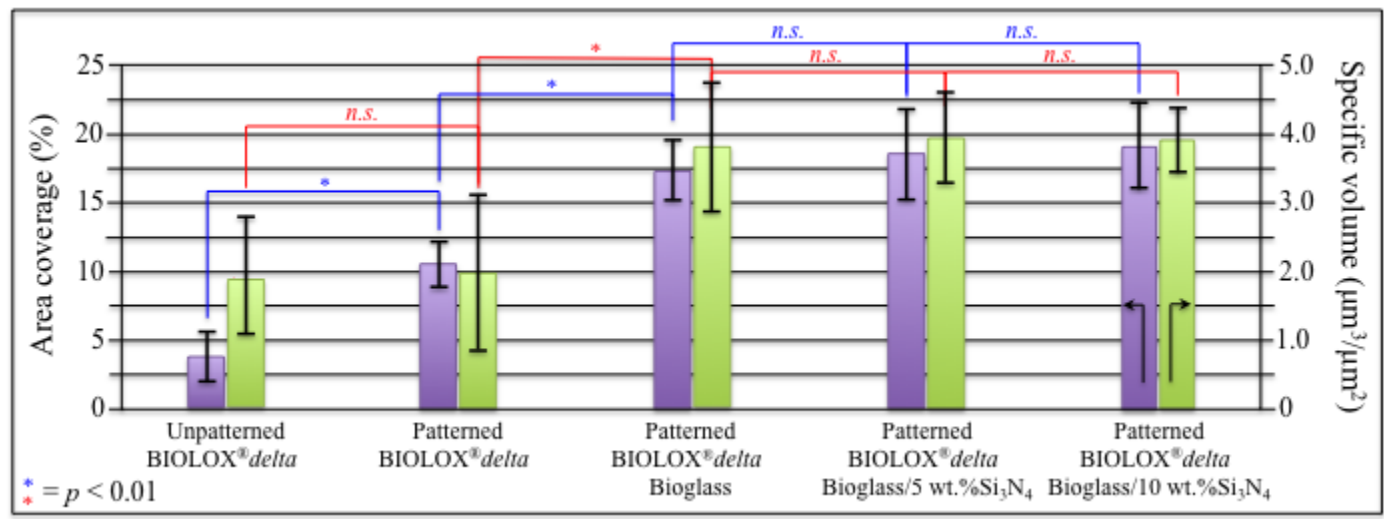

Figure 5. Quantitative laser microscopy data of area coverage and specific volume of biological tissue grown by osteoblasts on different substrates.
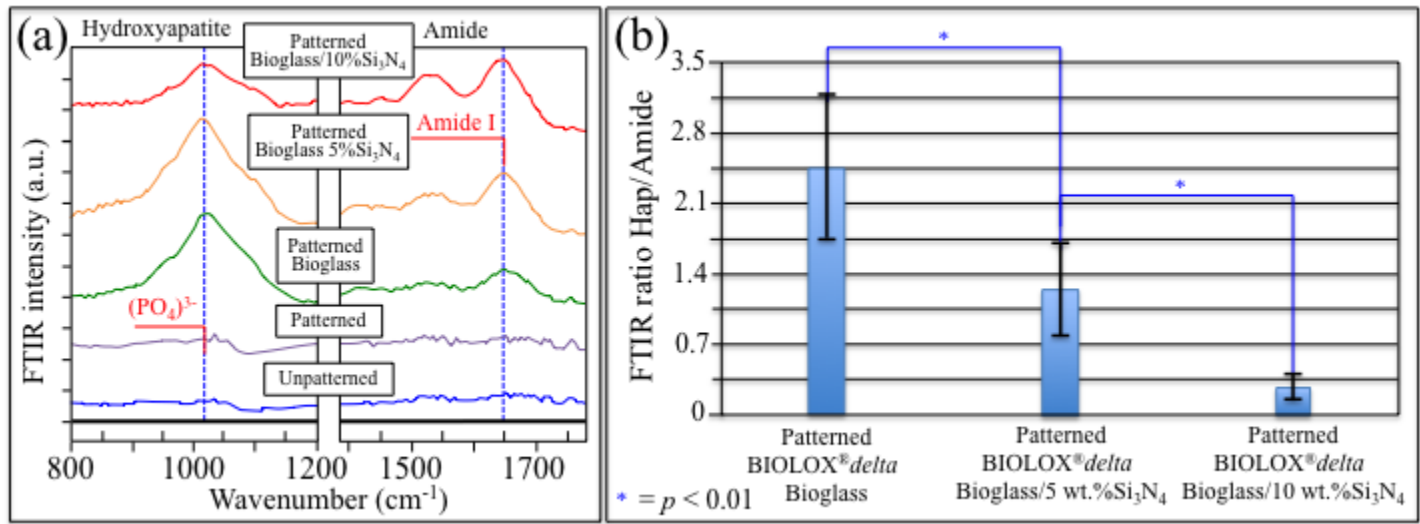

Figure 6. (a) Results of FTIR characterizations on unpatterned, patterned, and patterned/filled ZTA samples (sample specifications in labels); and, (b) plot of intensity ratios between apatite and organic matrix signals from FTIR spectra as a function of the type of ZTA substrate (cf. labels).

\subsection{Laser-Sintering of $\mathrm{Si}_{3} \mathrm{~N}_{4}$-Coated ZTA Surfaces}

Figure 7a,b show optical and laser micrographs, respectively, taken on the surface of a partly $\mathrm{Si}_{3} \mathrm{~N}_{4}$-coated ZTA surface across the interface between coated and uncoated regions (left and right sides of the micrographs, respectively). Figure $7 \mathrm{~b}$ shows that the average thickness of the $\mathrm{Si}_{3} \mathrm{~N}_{4}$ coating was in the order of $t=15 \pm 5 \mu \mathrm{m}$. The Raman spectra in the sections (c) and (d) of Figure 7 were taken on the ZTA uncoated and $\mathrm{Si}_{3} \mathrm{~N}_{4}$-coated sides, respectively. In (c), the ZTA spectrum is composed of several bands belonging to the tetragonal and the monoclinic zirconia polymorphs (labeled as $\mathrm{T}$ and $\mathrm{M}$, respectively) and one band from the alumina phase (at $\sim 397 \mathrm{~cm}^{-1}$; labeled A) [29]. Conversely, in the $\mathrm{Si}_{3} \mathrm{~N}_{4}$-coated area, the Raman spectrum only presents the $\mathrm{Si}-\mathrm{N}$ skeletal triplet at low frequencies and the Si-Si vibration band at $\sim 510 \mathrm{~cm}^{-1}$. This latter Raman band testifies the presence of free silicon clusters as a product of partial decomposition of the $\mathrm{Si}_{3} \mathrm{~N}_{4}$ structure during laser sintering [30].

Figure 8 shows SEM/EDS analyses performed on the same region in Figure 7 after 1-week in vitro exposure to SaOS-2 osteoblasts in biological environment. The main feature in the SEM micrograph (a) is the presence of a thick coverage of bony apatite only on the left side of the micrographs (i.e., the part coated with $\mathrm{Si}_{3} \mathrm{~N}_{4}$ ). EDS elemental analyses of $\mathrm{Si}, \mathrm{Al}$, and $\mathrm{Ca}$ (in (b), (c), and (d), respectively) revealed $\mathrm{Si}$-rich areas in coating area and no diffusional transport of the $\mathrm{Al}$ element into the coating during laser sintering (the very weak Al contamination in the coating area near the coated/uncoated interface, 
as seen in (c), is believed to arise from melting residues created during laser processing). The presence of $\mathrm{Si}$-rich areas conspicuously corresponded with the presence of $\mathrm{Ca}$ from bony hydroxyapatite.

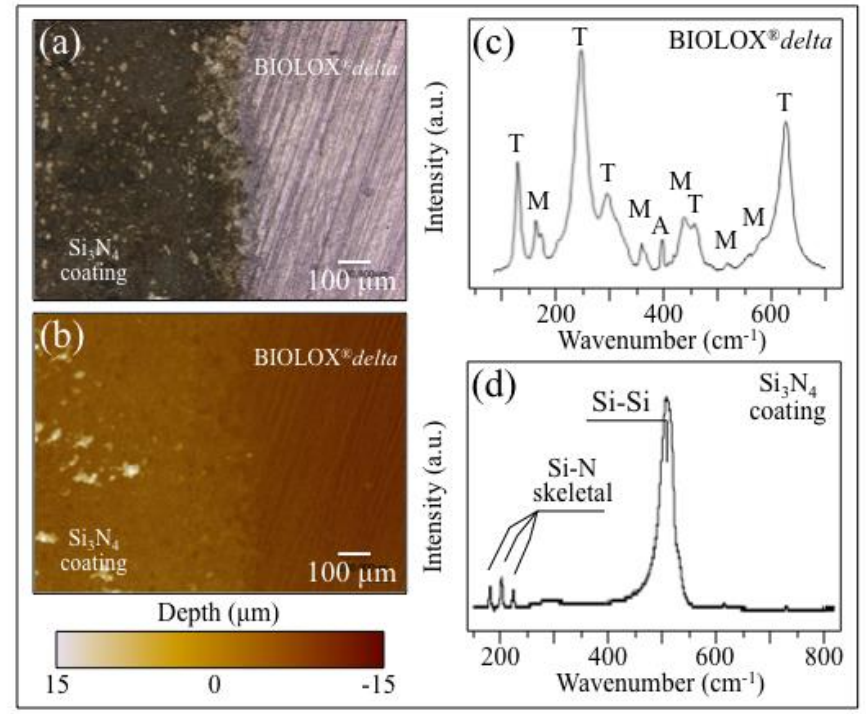

Figure 7. (a) Optical and (b) laser micrographs taken on the top surface of a partly $\mathrm{Si}_{3} \mathrm{~N}_{4}$-coated BIOLOX ${ }^{\circledR}$ delta ZTA surface across the interface between coated and uncoated regions (cf. labels); in $(\mathbf{c}, \mathbf{d})$, Raman spectra collected on the ZTA uncoated and $\mathrm{Si}_{3} \mathrm{~N}_{4}$-coated sides, respectively (labels explained in text).
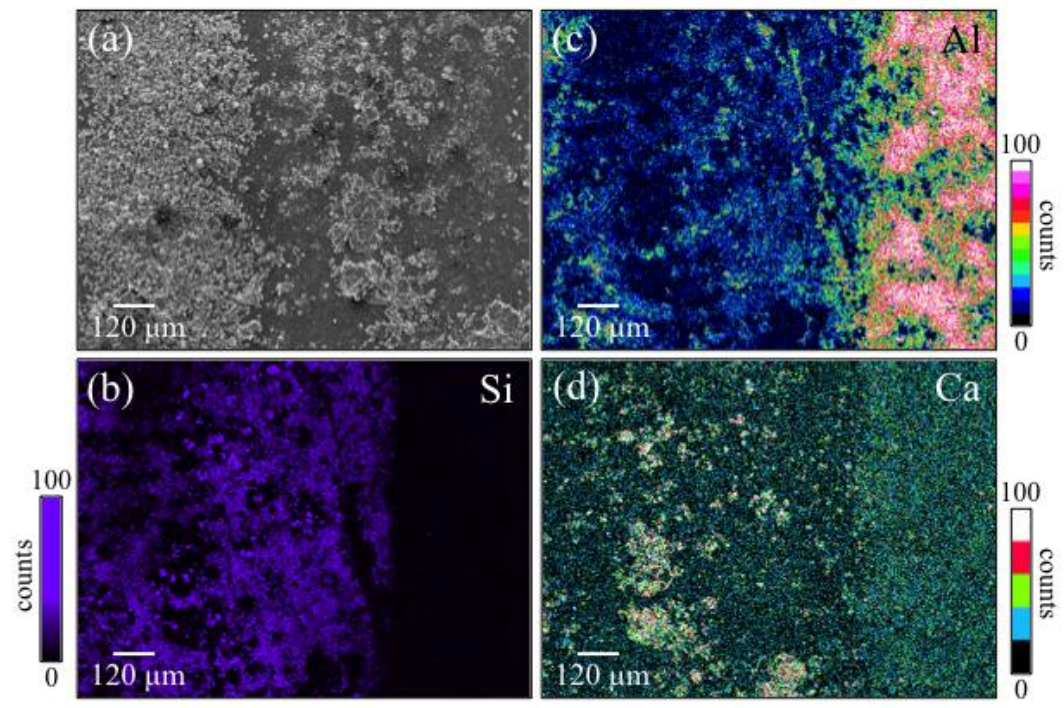

Figure 8. (a) SEM picture and EDS (Energy Dispersive X-ray Spectroscopy) maps of (b) Si, (c) Al, and (d) Ca collected in the same region shown in Figure 7 after 1-week in vitro exposure to SaOS-2 osteoblasts in biological environment.

Optical and laser micrographs of an island of bone tissue expressed by osteoblasts on the $\mathrm{Si}_{3} \mathrm{~N}_{4}$-coated side of the ZTA surface are shown in Figure 9a,b respectively. The three-dimensional laser microscopy view in section (c) of the same figure reveals the details of the bone structure elevation reaching $\sim 100 \mu \mathrm{m}$ above the plane of the coated structure. Average FTIR spectra collected in the neighborhood of the interface between $\mathrm{Si}_{3} \mathrm{~N}_{4}$-coated and ZTA uncoated zones (Figure 9d) revealed a four-fold higher intensity of the $\left(\mathrm{PO}_{4}\right)^{3-}$ band of mineral apatite in the former zone, as compared to the 
latter. In sum, the consistent findings using EDS, laser microscopy, and FTIR support the hypothesis that $\mathrm{Si}_{3} \mathrm{~N}_{4}$ enhanced the osteogenic properties of ZTA ceramic.
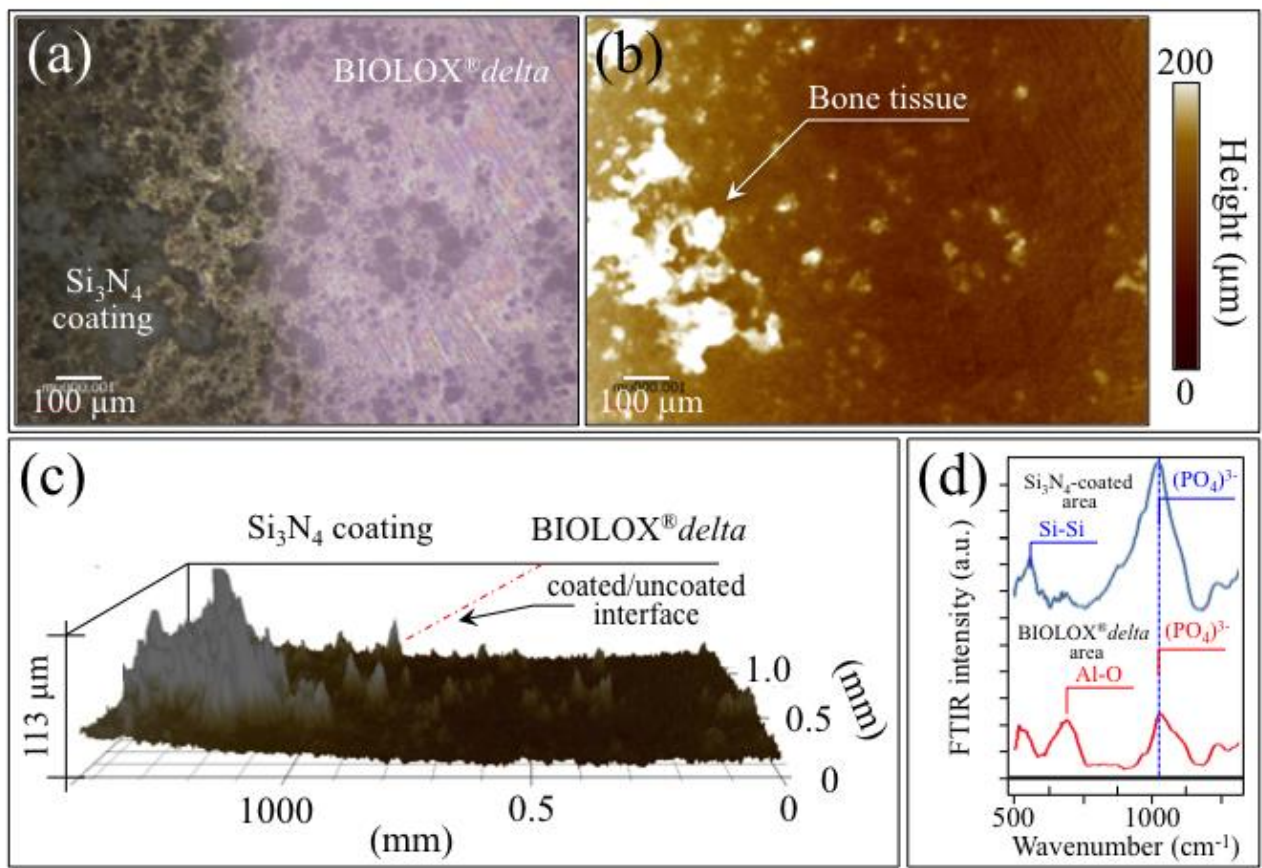

Figure 9. (a) Optical and (b) laser micrographs of a large island of bone tissue grown by osteoblasts on the $\mathrm{Si}_{3} \mathrm{~N}_{4}$-coated side of the BIOLOX ${ }^{\circledR}$ delta ZTA surface; (c) three-dimensional laser microscopy view of the same island of bone tissue; and, (d) average FTIR spectra collected in the neighborhood of the interface between $\mathrm{Si}_{3} \mathrm{~N}_{4}$-coated and ZTA uncoated zones including the $\left(\mathrm{PO}_{4}\right)^{3-}$ band of mineral apatite.

\section{Discussion}

Aluminum ions released by implant biomaterials may be toxic to bone [31]. Alumina coatings were designed to promote the osteointegration of prosthetic hip femoral stems, but this strategy created mineralization defects akin to those encountered in dialysis-induced osteomalacia, and related to $\mathrm{Al}^{3+}$ ionic accumulation in bone [32]. Histological analyses detected $\mathrm{Al}^{3+}$ ions released from the alumina coating, while X-ray diffractometry clarified the related structural modifications of periprosthetic bone tissue [32]. Follow up data at 2 5 years after implantation surgery showed that bone adjacent to alumina-coated stems had demineralized lamellar and Haversian structures because of $\mathrm{Al}^{3+}$ ion release from the alumina coating [32]. An in vivo animal study examined $\mathrm{Al}_{2} \mathrm{O}_{3}$-coated cylinders implanted in rabbit femoral condyles for one to six months [33]. Post-mortem analyses identified $\mathrm{Al}^{3+}$ ions at the interface between non-mineralized and mineralized bone; these ions reduced osteoblastic activity, induced apoptosis, and discouraged bone remodeling [17,34]. We recently compared in vitro osteoblastogenesis of mesenchymal cells cultured on $\mathrm{Al}_{2} \mathrm{O}_{3}$ versus other biomaterial substrates [35]. Raman spectral changes suggested a common apoptotic mechanism in cells exposed to Ti6Al4V alloy and $\mathrm{Al}_{2} \mathrm{O}_{3}$ substrates with intracellular biochemical changes consistent with toxicity [36]. These observations were consistent with the data of Brauchle et al. who monitored the Raman spectra of apoptotic osteosarcoma and chondrosarcoma cell lines in situ [37].

Aluminum interrupts osteoid calcification by preventing the growth of calcium phosphate crystals $[38,39]$. The material localizes at the bone mineralization front, where $\mathrm{Al}^{3+}$ ions inhibit calcification. $\mathrm{Al}^{3+}$ cations can substitute for $\mathrm{Ca}^{2+}$ in the structure of apatite [40], thereby locking the structure and inhibiting further mineralization [13].

Figure 10 describes the interaction between $\mathrm{ZTA}$ (which contains $\mathrm{Al}_{2} \mathrm{O}_{3}$ ) and apoptotic osteoblasts. The off-stoichiometry equations governing the cell/ZTA-substrate interactions in aqueous environments 
support $\mathrm{Al}^{3+}$ ion elution, and the formation of hydroxyl aluminols [41]. Other than incorporation in the apatite structure, $\mathrm{Al}^{3+}$ ions also undergo dissociative adsorption entailing the transfer of charge from the $\mathrm{Al}_{2} \mathrm{O}_{3}$ cluster to hydroxyl, oxygen, and proton radicals [12,42]. The consequent (exogenous) development of ROS at the biomolecular cell/substrate interface probably irreversibly damages proteins and nucleic acids, and causes peroxidation of membrane lipids, ultimately leading to cell apoptosis [16]. This hypothesized mechanism of action is consistent with previously published data showing no cell proliferation and osteogenesis inhibition on $\mathrm{Al}_{2} \mathrm{O}_{3}$ surfaces [35].

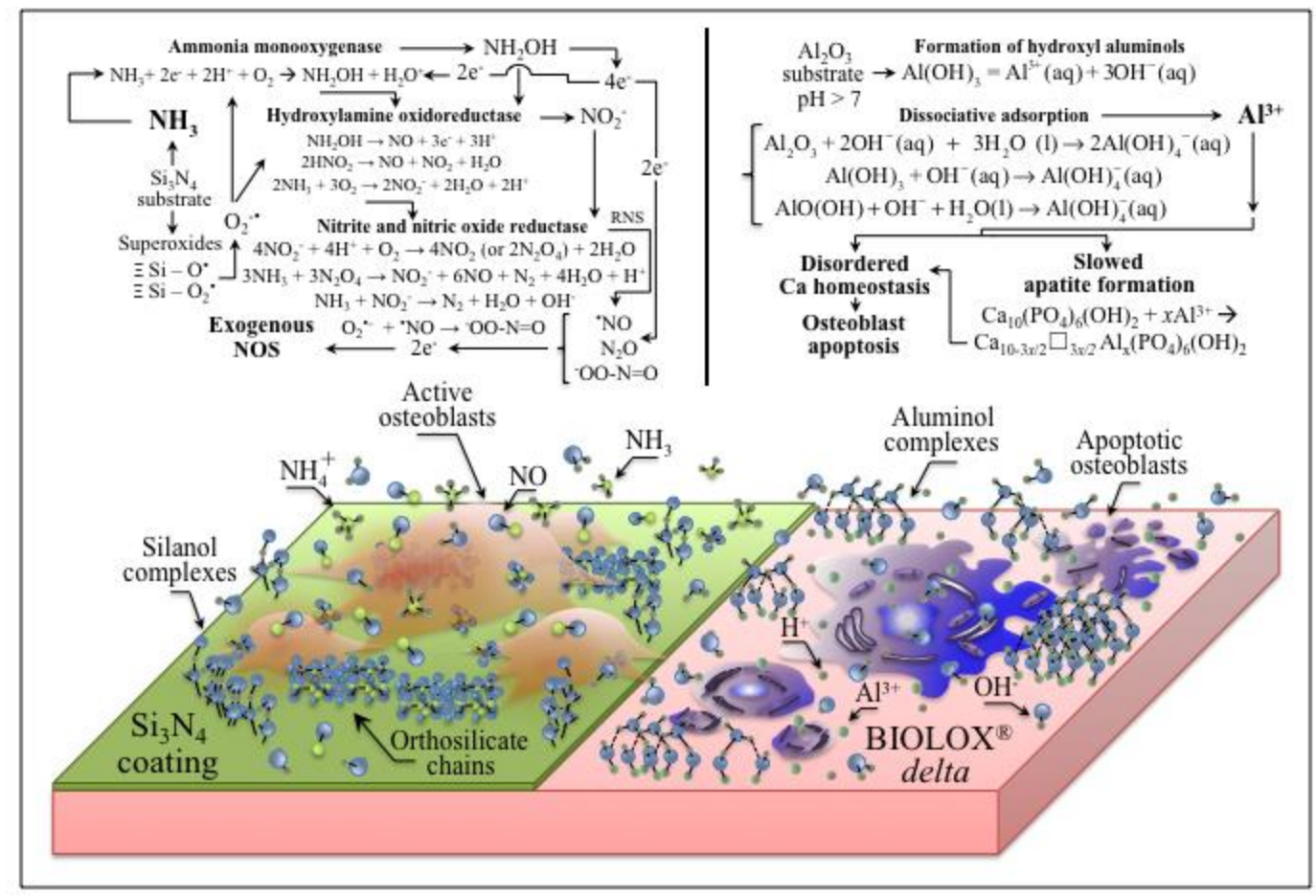

Figure 10. Schematic drafts of RNS- and silanol-based chemical interaction between $\mathrm{Si}_{3} \mathrm{~N}_{4}$ substrate and proliferating human osteoblasts (left side) and ROS- and aluminol-based chemical interaction between BIOLOX ${ }^{\circledR}$ delta ZTA and apoptotic osteoblasts (right side). The chemical reactions involved with the different substrates in aqueous solution are described on top of each side of the figure. The square box in the chemical formula of hydroxyapatite modified by $\mathrm{Al}^{3+}$ ions represents $\mathrm{Ca}$ vacancies.

Laser patterning and laser coating of ZTA with Bioglass ${ }^{\circledR}$ and/or $\mathrm{Si}_{3} \mathrm{~N}_{4}$ represent two approaches toward overcoming the above limitations. Bioglass ${ }^{\circledR} / \mathrm{Si}_{3} \mathrm{~N}_{4}$ mixtures stimulated osteoblast synthesis of bone tissue, the former favoring bone matrix mineralization and the latter enhancing cell proliferation and formation of bone matrix. The benefits of Bioglass ${ }^{\circledR}$ in surface mineralization [43]), and the favorable osteogenic chemistry of $\mathrm{Si}_{3} \mathrm{~N}_{4}$ [8-11] are already known. Figure 10 shows a schematic of the interaction between $\mathrm{Si}_{3} \mathrm{~N}_{4}$ and highly active osteoblasts, specifically the cascade of off-stoichiometric equations governing the cell/ $\mathrm{Si}_{3} \mathrm{~N}_{4}$-substrate interactions in aqueous environment. The surface kinetics following $\mathrm{Si}_{3} \mathrm{~N}_{4}$ hydrolysis leads to elution of $\mathrm{NH}_{4}{ }^{+} / \mathrm{NH}_{3}$ ions and the formation of hydroxyl silanols [44-46]. The availability of free electrons leads to decomposition of ammonia molecules with the formation of exogenous NO (used by the cells to signal further osteoblastogenesis) together with other RNS, while $\mathrm{NH}_{4}{ }^{+}$enters the cytoplasmic space through specific channels as a nutrient. Note that exogenous RNS are also capable to cleave phosphate groups, thus supporting endogenous ALP in increasing phosphate concentration [47]. Concurrently, the presence of silicic acid promotes osteogenesis [10,11]. 
Recent work has suggested the application of $\mathrm{Al}_{2} \mathrm{O}_{3}$ and ZTA in spine fusion and dental implants [48-52]. Biomaterial surface chemistry, and prior clinical experience with $\mathrm{Al}_{2} \mathrm{O}_{3}$-coated hip implants suggests caution, however. To combine the long-term structural reliability of ZTA with enhanced bone healing, surface functionalization with highly osteogenic materials like Bioglass ${ }^{\circledR} / \mathrm{Si}_{3} \mathrm{~N}_{4}$ may be a strategy to protect host tissues from aluminum ions, while promoting osteogenesis.

\section{Conclusions}

Commercially available ZTA surfaces were functionalized to improve their otherwise poor osteogenic properties. The response of SaOS-2 cells was monitored on: (i) ZTA ceramic surfaces patterned with cylindrical wells before and after filling in with Bioglass ${ }^{\circledR} / \mathrm{Si}_{3} \mathrm{~N}_{4}$ powder mixtures; and, (ii) ZTA surfaces coated with laser-sintered $\mathrm{Si}_{3} \mathrm{~N}_{4}$. Results showed that:

a. Osteoblasts cultured on ZTA underwent apoptosis from the surface chemistry of ZTA, such that no osteogenic properties were manifest on ZTA.

b. Surface patterning of ZTA surface with a cylindrical well grid (500 $\mu \mathrm{m}$ in diameter and depth) failed to improve cell proliferation and osteogenesis.

c. Filling the patterned wells with Bioglass ${ }^{\circledR}$ alone increased the amount of mineralized apatite on the ZTA surface, with no impact on cell proliferation.

d. Enhanced osteoblast proliferation and a favorable bone mineral/matrix ratio could be obtained by adding a $10 \mathrm{wt} . \%$ fraction $\mathrm{Si}_{3} \mathrm{~N}_{4}$ to the Bioglass ${ }^{\circledR}$ mixture.

e. Coating ZTA with a few $\mu \mathrm{m}$ thick sintered $\mathrm{Si}_{3} \mathrm{~N}_{4}$ layer enhanced osteogenesis by imparting the osteogenic properties of $\mathrm{Si}_{3} \mathrm{~N}_{4}$ onto ZTA.

In conclusion, with both techniques we successful obtained an improvement of the osteogenic properties of ZTA. This application can be of use in load-bearing applications where a good integration with the human body is required, as in spinal fusion cages, teeth implants and other applications that require contact with the human bone.

Author Contributions: Conceptualization, T.Y., N.K. and O.M.; Data curation, E.M.; Investigation, M.Z.; Methodology, F.B. and B.J.M.; Project administration, G.P.; Resources, M.Z., F.B., T.A. and T.Y.; Supervision, E.M., W.Z. and N.K.; Validation, B.S.B.; Writing-original draft, G.P.; Writing-review \& editing, E.M., W.Z., B.J.M., B.S.B. and O.M.

Funding: This research received no external funding.

Conflicts of Interest: B.S.B. and B.J.M. belong to SINTX Technologies Co., G.P. is a consultant to SINTX Technologies Co. The other authors declare no conflict of interest.

\section{References}

1. Jayakumar, P.; Di Silvio, L. Osteoblasts in bone tissue engineering. Proc. Inst. Mech. Eng. Part H J. Eng. Med. 2011, 224, 1415-1440. [CrossRef] [PubMed]

2. Hessle, L.; Johnson, K.A.; Clarke Anderson, H.; Narisawa, S.; Sali, A.; Goding, J.W.; Terkeltaub, R.; Millan, J.L. Tissue-nonspecific alkaline phosphatase and plasma cell membrane glycoprotein-1 are central antagonistic regulators of bone mineralization. Proc. Natl. Acad. USA 2002, 99, 9445-9449. [CrossRef] [PubMed]

3. Phadke, A.; Varghese, S. Synthetic biomaterials and stem cells for connective tissue engineering. In Molecular, Cellular, and Tissue Engineering; Bronzino, J.D., Peterson, D.R., Eds.; CRC Press: Boca Raton, FL, USA, 2015; pp. 146-163.

4. Hench, L.L. Bioceramics: From concept to clinic. J. Am. Ceram. Soc. 1991, 74, 1487-1510. [CrossRef]

5. Piconi, C. Bioinert Ceramics: State-of-the-Art. Key Eng. Mater. 2017, 758, 3-13. [CrossRef]

6. Webster, T.J.; Patel, A.A.; Rahaman, M.N.; Bal, B.S. Anti-infective and osteointegration properties of silicon nitride, poly(ether ether ketone), and titanium implants. Acta Biomater. 2012, 8, 4447-4454. [CrossRef] [PubMed]

7. Redza-Dutordoir, M.; Averill-Bates, D.A. Activation of apoptosis signaling pathways by reactive oxygen species. Biochim. Biophys. Acta Mol. Cell. Res. 2016, 1863, 2977-2992. [CrossRef] 
8. Pezzotti, G.; Bock, R.M.; Adachi, T.; Rondinella, A.; Boschetto, F.; Zhu, W.; Marin, E.; McEntire, B.J.; Bal, B.S.; Mazda, O. Silicon nitride surface chemistry: A potent regulator of mesenchymal progenitor cell activity in bone formation. Appl. Mater. Today 2017, 9, 82-95. [CrossRef]

9. Pezzotti, G.; McEntire, B.J.; Bock, R.; Boffelli, M.; Zhu, W.; Vitale, E.; Puppulin, L.; Adachi, T.; Yamamoto, T.; Kanamura, N.; et al. Silicon nitride: A synthetic mineral for vertebrate biology. Sci. Rep. 2016, 6, 31717. [CrossRef]

10. Pezzotti, G.; Marin, E.; Adachi, T.; Rondinella, A.; Boschetto, F.; Zhu, W.; Sugano, N.; Bock, R.M.; McEntire, B.; Bal, B.S. Bioactive silicon nitride: A new therapeutic material for osteoarthropathy. Sci. Rep. 2017, 7, 44848. [CrossRef]

11. Pezzotti, G.; Oba, N.; Zhu, W.; Marin, E.; Rondinella, A.; Boschetto, F.; McEntire, B.; Yamamoto, K.; Bal, B.S. Human osteoblasts grow transitional $\mathrm{Si} / \mathrm{N}$ apatite in quickly osseointegrated $\mathrm{Si}_{3} \mathrm{~N}_{4}$ cervical insert. Acta Biomat. 2017, 64, 411-420. [CrossRef]

12. Lu, Y.-H.; Chen, H.-T. Hydrogen generation by the reaction of $\mathrm{H}_{2} \mathrm{O}$ with $\mathrm{Al}_{2} \mathrm{O}_{3}$-based materials: A computational analysis. Phys. Chem. Chem. Phys. 2015, 17, 6834-6843. [CrossRef] [PubMed]

13. Blumenthal, N.C.; Posner, A.S. In vitro model of aluminum-induced osteomalacia: Inhibition of hydroxyapatite formation and growth. Calcif. Tissue Int. 1984, 36, 439-441. [CrossRef] [PubMed]

14. Campbell, A.; Becaria, A.; Lahiri, D.K.; Sharman, K.; Bondy, S.C. Chronic exposure to aluminum in drinking water increases inflammatory parameters selectively in the brain. J. Neurosci. Res. 2004, 75, 565-572. [CrossRef] [PubMed]

15. Chambers, J.W.; LoGrasso, P.V. Mitochondrial c-Jun N-terminal kinase (JNK) signaling initiates physiological changes resulting in amplification of reactive oxygen species generation. J. Biol. Chem. 2011, 286, 16052-16062. [CrossRef] [PubMed]

16. Tournier, C.; Hess, P.; Yang, D.D.; Xu, J.; Turner, T.K.; Nimnual, A.; Bar-Sagi, D.; Jones, S.N.; Flavell, R.A.; Davis, R.J. Requirement of JNK for stress-induced activation of the cytochrome c-mediated death pathway. Science 2000, 288, 870-874. [CrossRef]

17. Li, X.; Han, Y.; Guan, Y.; Zhang, L.; Bai, C.; Li, Y. Aluminum induces osteoblast apoptosis through the oxidative stress-mediated JNK signaling pathway. Biol. Trace Elem. Res. 2012, 150, 502-508. [CrossRef]

18. Feng, X.; McDonald, J.M. Disorders of bone remodeling. Annu. Rev. Pathol. 2011, 6, 121-145. [CrossRef]

19. Zayzafoon, M.; Fulzele, K.; McDonald, J.M. Calmodulin and calmodulin-dependent kinase II $\alpha$ regulate osteoblast differentiation by controlling c-fos expression. J. Biol. Chem. 2005, 280, 7049-7059. [CrossRef]

20. Yeo, H.; McDonald, J.M.; Zayzafoon, M. NFATcl: A novel anabolic therapeutic target for osteoporosis. Ann. NY Acad. Sci. 2006, 1068, 564-567. [CrossRef]

21. Yeo, H.; Beck, L.H.; McDonald, J.M.; Zayzafoon, M. Cyclosporin A elicits dose-dependent biphasic effects on osteoblast differentiation and bone formation. Bone 2007, 40, 1502-1516. [CrossRef]

22. R Core Team. R: A Language and Environment for Statistical Computing; R Foundation for Statistical Computing: Vienna, Austria, 2013; Available online: http://www.R-project.org/ (accessed on 2 October 2019).

23. Marin, E.; Horiguchi, S.; Zanocco, M.; Boschetto, F.; Rondinella, A.; Zhu, W.; Bock, R.M.; McEntire, B.J.; Adachi, T.; Bal, B.S.; et al. Bioglass functionalization of laser-patterned bioceramic surfaces and their enhanced bioactivity. Heliyon 2018, 4, e01016. [CrossRef] [PubMed]

24. Wang, X.; Xu, S.; Zhou, S.; Xu, W.; Leary, M.; Choong, P.; Qian, M.; Brandt, M.; Xie, Y.M. Topological design and additive manufacturing of porous metals for bone scaðolds and orthopaedic implants: A review. Biomater 2016, 83, 127-141. [CrossRef] [PubMed]

25. Perez, R.A.; Mestres, G. Role of pore size and morphology in musculo-skeletal tissue regeneration. Mater. Sci. Eng. C 2016, 61, 922-939. [CrossRef] [PubMed]

26. Jian, Y.-T.; Yang, Y.; Tian, T.; Stanford, C.; Zhang, X.-P.; Zhao, K. Effect of pore size and porosity on the biomechanical properties and cytocompatibility of porous NiTi alloys. PLoS ONE 2015, 10, e0128138. [CrossRef] [PubMed]

27. Chen, S.; Guo, Y.; Liu, R.; Wu, S.; Fang, J.; Huang, B.; Li, Z.; Chen, Z.; Chen, Z. Tuning surface properties of bone biomaterials to manipulate osteoblastic cell adhesion and the signaling pathways for the enhancement of early osseointegration. Colloids Surf. B Biointerfaces 2018, 164, 58-69. [CrossRef] 
28. Boskey, A.L. Bone composition: Relationship to bone fragility and antiosteoporotic drug effects. BoneKEy Rep. 2013, 2, 447. [CrossRef]

29. Pezzotti, G.; Yamada, K.; Sakakura, S.; Pitto, R.P. Raman spectroscopic analysis of advanced ceramic composite for hip prosthesis. J. Am. Ceram. Soc. 2008, 91, 1199-1206. [CrossRef]

30. Sergo, V.; Pezzotti, G.; Katagiri, G.; Muraki, N.; Nishida, T. Stress dependence of the Raman spectrum of $\beta$-silicon nitride. J. Am. Ceram. Soc. 1996, 79, 781-784. [CrossRef]

31. Chappard, D.; Bizot, P.; Mabilleau, G.; Hubert, L. Aluminum and bone: Review of new clinical circumstances associated with $\mathrm{Al}^{3+}$ deposition in the calcified matrix of bone. Morphologie 2016, 100, 95-105. [CrossRef]

32. Savarino, L.; Cenni, E.; Stea, S.; Donati, M.E.; Paganetto, G.; Moroni, A.; Toni, A.; Pizzoferrato, A. X-ray diffraction of newly formed bone close to alumina- or hydroxyapatite-coated femoral stem. Biomaterials 1993, 14, 900-905. [CrossRef]

33. Frayssinet, P.; Tourenne, F.; Rouquet, N.; Bonel, G.; Conte, P. Biological effects of aluminium diffusion from plasma-sprayed alumina coatings. J. Mater. Sci. Mater. Med. 1994, 5, 491-494. [CrossRef]

34. Rodriguez, M.; Felsenfeld, A.J.; Llach, F. Aluminum administration in the rat separately affects the osteoblast and bone mineralization. J. Bone Miner. Res. 1990, 5, 59-67. [CrossRef] [PubMed]

35. Pezzotti, G.; Adachi, T.; Boschetto, F.; Zhu, W.; Zanocco, M.; Marin, E.; Bal, B.S.; McEntire, B.J. Off-stoichiometric reactions at the cell/substrate biomolecular interface: In situ and ex situ monitoring of cell proliferation, differentiation, and bone tissue formation. Int. J. Mol. Sci. 2019, 17, 4080. [CrossRef] [PubMed]

36. Notingher, I.; Green, C.; Dyer, C.; Perkins, E.; Hopkins, N.; Lindsay, C.; Hench, L.L. Discrimination between ricin and sulphur mustard toxicity in vitro using Raman spectroscopy. J. R. Soc. Interface 2004, 1, 79-90. [CrossRef] [PubMed]

37. Brauchle, E.; Thude, S.; Bruker, S.Y.; Schenke-Layland, K. Cell death stages in single apoptotic and necrotic cells monitored by Raman microspectroscopy. Sci. Rep. 2014, 4, 4698. [CrossRef] [PubMed]

38. Liu, C.C.; Howard, G.A. Effects of aluminum on bone in vitro. Clin. Res. 1984, 32, 50A.

39. Severson, A.R.; Haut, C.F.; Firling, C.E.; Huntley, T.E. Influence of short-term aluminum exposure on demineralized bone matrix induced bone formation. Arch. Toxicol. 1992, 66, 706-712. [CrossRef]

40. Elliott, J.C. Structure and chemistry of the apatites and other calcium orthophosphates. In Studies in Inorganic Chemistry; Elsevier: Amsterdam, The Netherlands, 2018; Volume 18.

41. Shapovalov, V.; Truong, T.N. Ab Initio study of water adsorption on $\alpha-\mathrm{Al}_{2} \mathrm{O}_{3}(0001)$ crystal surface. J. Phys. Chem. B 2000, 104, 9859-9863. [CrossRef]

42. Fernández, E.M.; Eglitis, R.I.; Borstel, G.; Balbás, L.C. Ab initio calculations of $\mathrm{H}_{2} \mathrm{O}$ and $\mathrm{O}_{2}$ adsorption on $\mathrm{Al}_{2} \mathrm{O}_{3}$ substrates. Comput. Mater. Sci. 2007, 39, 587-592. [CrossRef]

43. Kaur, G.; Pandey, O.P.; Singh, K.; Homa, D.; Scott, B.; Pickrell, G. A review of bioactive glasses: Their structure, properties, fabrication and apatite formation. J. Biomed. Mater. Res. Part A 2014, 102, 254-274. [CrossRef]

44. Kajdas, C. General approach to mechanochemistry and its relation to tri- biochemistry. In Tribology in Engineering; InTech: Rijeka, Croatia, 2013; pp. 209-240.

45. Mezzasalma, S.; Baldovino, D. Characterization of silicon nitride surface in water and acid environment: A general approach to the colloidal suspensions. J. Colloid Interface Sci. 1996, 180, 413-420. [CrossRef]

46. Sonnefeld, J. Determination of surface charge density parameters of silicon nitride. Colloids Surf. A 1996, 108, 27-31. [CrossRef]

47. Fedor, M.J.; Williamson, J.R. The Catalytic Diversity of RNAs. Nat. Rev. Mol. Cell Biol. 2005, 6, $399-412$. [CrossRef] [PubMed]

48. Schierano, G.; Mussano, F.; Faga, M.G.; Menicucci, G.; Manzella, C.; Sabione, C.; Genova, T.; von Degerfeld, M.M.; Peirone, B.; Cassenti, A.; et al. An alumina toughened zirconia composite for dental implant application: In vivo animal results. Biomed. Res. Int. 2015, 2015, 157360. [CrossRef] [PubMed]

49. Piconi, C.; Sandri, M. New materials for dental implantology. Key Eng. Mater. 2017, 750, 189-194. [CrossRef]

50. Kohal, R.-J.; Att, W.; Baechle, M.; Bitz, F. Ceramic abutments and ceramic oral implants. An update. Periodontology 2000 2008, 47, 224-243. [CrossRef] 
51. Oda, Y.; Miyatake, S.; Tokuriki, Y.; Handa, H. Alumina-ceramics (Bioceram) as the implant material in anterior cervical fusion. Nihon Geka Hokan 1981, 50, 352-357.

52. Mostofi, K.; Moghaddam, B.G.; Peyravi, M.; Khouzani, R.K. Preliminary results of anterior cervical arthroplasty by porous alumina ceramic cage for cervical disc herniation surgery. J. Craniovertebral Junction Spine 2018, 9, 223-226. [CrossRef]

(c)

(C) 2019 by the authors. Licensee MDPI, Basel, Switzerland. This article is an open access article distributed under the terms and conditions of the Creative Commons Attribution (CC BY) license (http://creativecommons.org/licenses/by/4.0/). 